\title{
重症頭部外傷における低体温療法時の循環・呼吸器合併症
}

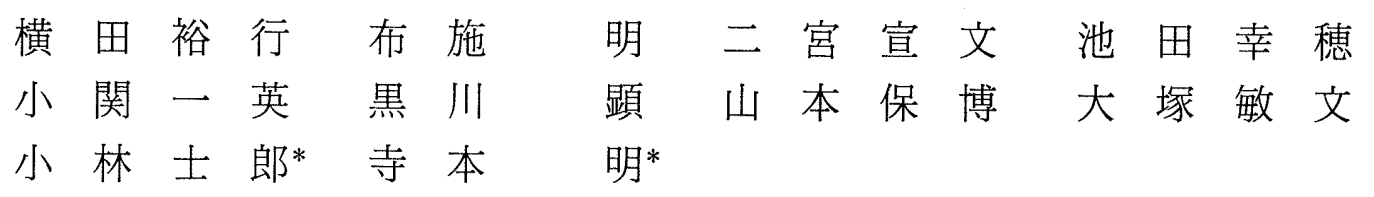

\section{Complications of the Hemodynamic and Respiratory Systems during Hypothermal Treatment for Severe Head Injury \\ by}

Hiroyuki Yokota, M.D., Akira Fuse, M.D., Norihumi Ninomiya, M.D., Yukio Ikeda, M.D., Kazuhide Koseki, M.D., Akira Kurokawa, M.D., Yasuhiro Yamamoto, M.D., Toshibumi Otsuka, M.D., Shiro Kobayashi, M.D.*, and Akira Teramoto, M.D.*

from

Departments of Critical Care Medicine and *Neurosurgery, Main Hospital, Nippon Medical School

The complications of mild hypothermia in 39 patients suffering from a severe head injury and with a Glasgow Coma Scale rating of less than 8 on admission were discussed, especially with respect to cardiopulmonary function, hemodynamic function, and infections of the respiratory system. The patients were treated using mild hypothermia, according to the protocol of our institute, to control intracranial pressure(ICP) and to prevent secondary neuronal damage. In these patients the following were continuously recorded: ICP, the saturation of jugular oxygen $\left(\mathrm{SjO}_{2}\right)$, and hemodynamic function using a thermodilution ( $\mathrm{Swan}-\mathrm{Ganz}$ ) catheter. A patient's white blood cells $(\mathrm{WBC})$ and c-reactive protein were checked each day as an indication of possible infection. The sputum and urine were cultured, and every two days a chest X-ray was taken to detect the possibility of pneumonia.

Cerebral perfusion pressure (CPP) and ICP were decreased after the commencement of mild hypothermia. The value of $\mathrm{SjO}_{2}$ suggested recovery from cerebral ischemia during, and after, the treatment with hypothermia. Systemic and pulmonary vascular resistance, the WBC and CPP were significantly increased during the mild hypothermia. Pathogenic organisms were isolated in $73.5 \%$ of the patients, and these included: Pseudomonas aeruginosa, meticillin resistant Staphylococcus aureus (MRSA), and Klebsiella pneumoniae.

Our study suggests that mild hypothermia for the treatment of severe head injury is effective for controlling ICP and preventing cerebral ischemia, and that it is necessary to test for systemic complications such as hemodynamic suppression and for pneumonia.

(Received May 6, 1997; accepted October 15, 1997)

Key words : mild hypothermia, severe head injury, complication

Jpn J Neurosurg (Tokyo) $7: 9-13,1998$

\section{はじめに}

最近，重症頭部外傷の治療の際，脳代謝や脳血流を考 慮した neurointensive careが行われるようになってき
た。これらの中で重症頭部外傷に対しての低体温療法が 注目されている，そこで，われわれは重症頭部外傷急性 期に低体温療法を行った症例を retrospective に検討 し, 低体温療法に伴う合併症, 特に循環器機能への影響

日本医科大学救急医学教室/ $\bar{\top} 113-0022$ 文京区千駄木 1-1-5〔連絡先：横田裕行〕

Address reprint requests to: Hiroyuki Yokota, M.D., Department of Critical Care Medicine, Main Hospital, Nippon Medical School, 1-1-5 Sendagi, Bunkyo-Ku, Tokyo 113-0022, Japan

*同脳神経外科 
Table 1 Intracranial lesions

\begin{tabular}{cc}
\hline Focal brain injury & 26 cases \\
cerebral contusion & 12 \\
subdural hematoma & 11 \\
epidural hematoma & 3 \\
Diffuse brain injury & 13 cases \\
\hline
\end{tabular}

や呼吸器感染症に対して若干の知見を得たので報告す z.

\section{対 象}

対象は最近 2 年間に当施設, および関連施設に入院加 療し, 当施設の重症頭部外傷マニュアルにより, 低体温 療法の適応ありと判断された 39 例である。すなわち, 来 院時 Glasgow Coma Scale（GCS）が 8 以下の重症単独 頭部外傷例の中で，持続内頸静脈酸素飽和度測定 $\left(\mathrm{SjO}_{2}\right)$ にてその值が $60 \%$ 以下を示し, 頭蓋内圧（ICP）が 20 $\mathrm{mmHg}$ 以上で推移する症例である ${ }^{12)}$.これらの症例の頭 蓋内病変はび漫性脳損傷 13 例, 局所性脳損傷 26 例であ った (Table 1). 年齢は 1.3 81 歳, 平均 36.9 歳, 男性 29 例, 女性 10 例で, いずれも合併症として予想される心 肺機能低下や呼吸器合併症に耐え得ると考えられ，患者 家族に十分なインフォームドコンセントが得られた症例 である。また，多発外傷例は除外し，頭部単独外傷を対 象とした.

\section{方 法}

冷却開始はできるだけ早期とし，受傷後少なくとも 6 時間以内とし，その方法は冷却用ブランケット 2 枚で患 者の体幹を挟むように行った，目標温度は脳表温度，あ

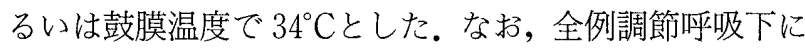
呼吸管理を行った。深部体温, 脳表温度, $\mathrm{ICP}$ おび $\mathrm{SjO}_{2}$ を測定し，その結果を低体温療法導入直前，導入中，お よび終了後に分類し，此較検討をした。なお，導入中の 測定結果の平均值は 1 時間ごとの各パラメータの平均と した。導入直前, 終了後の測定結果の平均は低体温療法 導入前 1 時間，あるいは常温に復温後 1 時間の各パラメ 一タの平均とした。また，呼吸状態の指標として血液ガ ス, エンドタイダル $\mathrm{CO}_{2}$, 心肺機能の指標として SwanGanz カテーテルによる循環機能測定, 血液凝固系検査 を行った，脳表温度は，開頭時あるいは第頭時にサーミ ス夕（SHERIDON 社製 SHERI-I-TEMP）を脳表に留 置し, 継続的に測定した. 鼓膜温度は赤外線温度計 （ARGYLE 社製 GENIUS）にて測定した。冷却中の悪
Table 2 Course of rectal and cortical temperature, mean arterial pressure (MAP) and intracranial pressure (ICP)

\begin{tabular}{lccc}
\hline & Pre & Hypothermia & Post \\
\hline Rectal temperature $\left({ }^{\circ} \mathrm{C}\right)$ & $36.9 \pm 1.0$ & $33.2 \pm 1.6^{*}$ & $37.6 \pm 0.6$ \\
Cortical temperature $\left({ }^{\circ} \mathrm{C}\right)$ & $36.5 \pm 1.2$ & $33.3 \pm 1.6^{*}$ & $37.4 \pm 0.4$ \\
$\mathrm{MAP}(\mathrm{mmHg})$ & $147.5 \pm 17.3$ & $101.1 \pm 5.1^{*}$ & $102.6 \pm 4.1^{*}$ \\
$\mathrm{ICP}(\mathrm{mmHg})$ & $26.2 \pm 24.5$ & $11.4 \pm 3.3^{*}$ & $10.5 \pm 1.5^{*}$ \\
\hline
\end{tabular}

$*<0.01 \quad \mathrm{n}=39$

寒・戦慄には非脱分極性筋弛緩剤，midazoram などの鎮 静剂を使用した。低体温中は平均血圧を $70 \mathrm{mmHg}$ 以上 に保つようにドパミンを使用した，復温時期は頭蓋内圧 が 36 時間以上 $20 \mathrm{mmHg}$ 以下で経過した時点とし, 復温

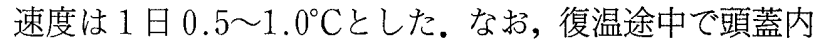
圧が上昇する症状に対しては, 再度冷却を行った。血液・ 生化学的検査は連日, 喀痰や尿培養は隔日施行した。

\section{結 果}

これら 39 症例における低体温療法の開始は受傷後 4〜24 時間, 平均 8.5 時間であり, 期間は 41〜120 時間, 平均 69.3 時間であった。なお，これらの症例のうち，低 体温療法を途中で中断した症例はなかった. 39 例の退院 時の Glasgow Outcome Scale(GOS) は, good recovery (GR) と moderate disability（MD）の予後良好群が 16 例, severe disability (SD) と vegetative state (VS) の予後不良群が 12 例，死亡 11 例であった。

直腸温，脳表温度，平均血圧および頭蓋内圧の推移を

Table 2 に示した。低体温療法中は直腸温 $33.2 \pm 1.6^{\circ} \mathrm{C}$, 脳表温度 $33.3 \pm 1.6^{\circ} \mathrm{C}$, 平均血圧 $101.1 \pm 5.1 \mathrm{mmHg}$ お よび ICP $11.4 \pm 3.3 \mathrm{mmHg}$ といずれも低体温導入前と 比較して有意に低下した，さらに，平均血圧と頭蓋内圧 は低体温療法終了後も導入前に比して低值を示した (Table 2).

脳血流と脳酸素代謝の比でその值が決定される $\mathrm{SjO}_{2}$ 值は，低体温療法中は上昇する傾向が認められた。すな わち, 低体温療法施行前の $\mathrm{SjO}_{2}$ は $55.3 \%$ であったが, 低 体温療法中は $69.0 \%$ にまで上昇し, 終了後も $66.5 \%$ と正 常值を示した（Table 3).

循環機能測定では，末梢血管抵抗や肺血管抵抗が低体 温療法中に著明に上昇した。全身の酸素消費量 低体温 療法中は著明に低下し，終了後上昇した(Table 4)。これ らの変化は統計学的に有意であった。

感染徴候の推移をみると, 白血球数は有意な変化は認 めなかったが, CRP は有意に上昇し, 復温後もその傾向 が持続した。 また，赤血球数は低体温中に有意に減少し， 
Table 3 Chages of jugular oxygen saturation $\left(\mathrm{SjO}_{2}\right)$ in treatment of hypothermia

\begin{tabular}{l|ccc}
\hline & Pre $^{-}$ & Hypothermia & Post- \\
\hline $\mathrm{SjO}_{2}(\%)$ & $55.3 \pm 3.8$ & $69.0 \pm 14.4$ & $66.5 \pm 12.5$ \\
\hline $\mathrm{n}=39$ & & &
\end{tabular}

Table 5 Change of RBC, WBC and CRP in treatment of hypothermia

\begin{tabular}{l|ccc}
\hline & Pre- & Hypothermia & Post- \\
\hline $\operatorname{RBC}\left(\times 10^{4}\right)$ & $456 \pm 51$ & $376 \pm 60^{*}$ & $374 \pm 84^{*}$ \\
$\mathrm{WBC}\left(\times 10^{4}\right)$ & $1.70 \pm 0.51$ & $1.62 \pm 0.67$ & $1.80 \pm 0.59$ \\
$\mathrm{CRP}$ & $1.0 \pm 1.8$ & $17.1 \pm 10.5^{*}$ & $9.4 \pm 5.4^{*}$ \\
\hline$*<0.01 \quad \mathrm{n}=39$ & &
\end{tabular}

Table 7 Relationship between duration of hypothermia and sputum culture

\begin{tabular}{c|cc}
\hline & $<72$ hours & $>72$ hours \\
\hline Positive & 4 cases & 12 cases \\
Negative & 3 & 0 \\
\hline $\mathrm{p}<0.001$ & \multicolumn{3}{l}{}
\end{tabular}

その傾向は復温後も持続した (Table 5). 39 例中 19 例に 複数回喀痰培養が施行されたが，陰性であった症例はわ ずかに 3 例 $15.8 \%$ ので，残りの 16 例 $84.2 \%$ にはな らかの細菌が検出された。特に，緑膿菌と多剤耐性ブド ウ球菌 (MRSA) が高頻度に検出され，前者は 16 例中 10 例, 55 回検出され，後者は 7 例に計 61 回検出さた。この ほか Klebsiella pneumoniae, acinetobactor calcoacetius, serratia marcescens も検出された (Table 6). 喀痰加らの 細菌検出率は, 低体温療法が 72 時間以上の症例で有意に 後者が高值であった（Table 7)。

\section{考 察}

\section{1 低体温療法に関して}

重症頭部外傷の治療に際して，従来ならぼ頭蓋内圧䒕 進に対し，一律に高浸透圧利尿剂の投与や軽度過換気療 法が施行されていた。しかし，脳血流や脳酸素代謝の面 から，病態によっては過換気療法を解除する必要性があ ることが明らかとなった ${ }^{11)}$ 。このような治療の中で最近 注目されているのが軽度低体温療法である。低体温はそ の温度によって 5 段階に分類されている.すなわち， $34 \sim 36^{\circ} \mathrm{C}$ の mild hypothermia $(\mathrm{H})$ (軽度低体温), $28 \sim 32^{\circ} \mathrm{C}$ の moderate $\mathrm{H}, \quad 15 \sim 25^{\circ} \mathrm{C}$ の deep $\mathrm{H}, \quad 5 \sim 15^{\circ} \mathrm{C}$ の profound $\mathrm{H}$ ，および $5{ }^{\circ} \mathrm{C}$ 以下の ultraprofound $\mathrm{H}$ であ る。そもそも低体温療法は 1950 年代から心臓外科や脳外 科の分野で行われていたが，それらの多くは術中脳虚血 を予防する目的で moderate $\mathrm{H}$ を一時的に施行したも ので，手術法の進歩により最近はあまり行われなくなつ
Table 4 Hemodynamic changes associated with treatment using hypotiermia

\begin{tabular}{l|cc}
\hline & Hypothermia & Post \\
\hline PVRI $\left(\right.$ dyne sec $\left./ \mathrm{cm}^{-5} \cdot \mathrm{m}^{2}\right)$ & $366.5 \pm 14.5^{*}$ & $296.8 \pm 50.0$ \\
SVRI $\left(\right.$ dyne sec $\left./ \mathrm{cm}^{-5} \cdot \mathrm{m}^{2}\right)$ & $2524.8 \pm 519.6^{*}$ & $2004.6 \pm 430.1$ \\
$\mathrm{VO}_{2}\left(\mathrm{ml} / \mathrm{min}^{-1}\right)$ & $109.0 \pm 46.9^{*}$ & $220.3 \pm 99.7$ \\
\hline
\end{tabular}

PVRI : pulmonary vascular resistance index

SVRI : systemic vascular resistance index

$\mathrm{VO}_{2}: \mathrm{O}_{2}$ consumption

$*<0.01 \quad \mathrm{n}=39$

Table 6 Pathogens detected during hypothermia

\begin{tabular}{cc}
\hline Sputum culture & 19 cases \\
Positive & 16 cases \\
Pseudomonas aeruginosa & $10 / 16(62.5 \%)$ \\
MRSA & $7 / 16(43.8 \%)$ \\
Klebsiella pneumoniae & $4 / 16(25.0 \%)$ \\
Acinetobactor calcoacetius & $3 / 16(18.8 \%)$ \\
Serratia marcescens & $3 / 16(18.8 \%)$ \\
PSeudomonas cepacia & $1 / 16(6.3 \%)$ \\
Enterococcus sp. & $1 / 16(6.3 \%)$ \\
Negative & 3 cases \\
\hline
\end{tabular}

ていた. 1988 年 Safer ら ${ }^{8)}$ が軽度低体温での脳保護作用 を明らかにしたことで，再び注目されるようになり，頭 部外傷患者の軽度低体温療法の有用性が報告されるよう になった 2)599).しかし，いずれの報告でも低体温療法は その効果とともに呼吸器系・循環器系, あるいは凝固系 の重篤な合併症を伴いやすいことが強調されている6 ${ }^{6}$.

\section{2 脳灌流圧との関連}

Frank $ら^{3)}$ は，軽度低体温状態では有意に心筋の虚血 が生じることを強調している.また Boelhouwer ら1)は， 軽度低体温状態がカリウムの細胞内移行を助長させるこ とで低 $\mathrm{K}$ 血症を引き起こし，心筋合併症の頻度を増加さ せると報告している，今回の結果では，低体温療法中あ るいは復温後, 頭蓋内圧は低体温療法前に比して低下し た。しかし，同時に心筋収縮力や循環機能の悪化からい ずれの症例も平均血圧が低下し，しかもその程度は頭蓋 内压の低下の程度より大きいことが明らかとなった。し たがって，平均血圧と頭蓋内圧の差によって定義される 脳灌流圧は低体温療法中や復温後は，低体温導入前より 低值となった。低体温中の至適脳灌流圧に関してはいま だ報告がないが，少なくとも脳の自動調節能が破綻する とされる平均血圧が $60 \mathrm{mmHg}$ 以下での全身管理は慎ま なければならないと考える。平均血压を $70 \mathrm{mmHg}$ 以上 に保つには， $\beta_{1}$ 作用の強い各種カテコールアミンを使用 することが望ましいと考えている。 


\section{3 脳酸素代謝および脳血流}

適切な呼吸・循環管理がなされている場合, $\mathrm{SjO}_{2}$ の正 常值は 60〜 80\%であるとされている ${ }^{10)}$. 今回の症例での 低体温療法前 $\mathrm{SjO}_{2}$ が $55.3 \%$ あったことは, 頭蓋内圧 六進やその他の原因により，これら対象症例が脳虚血状 態であったことを裏づけている。

Reuler ${ }^{7)}$ は体温を $1^{\circ} \mathrm{C}$ 低下させると脳代謝は $5 \%$ 減少 すると報告し, Young ら ${ }^{13)}$ は体温が $1^{\circ} \mathrm{C}$ 低下することで 脳血流や脳酸素摂取率が $5 \%$ 低下すると報告している. 低体温療法で $\mathrm{SjO}_{2}$ が正常化したことは, 脳血流に比し て脳酸素代謝がより低下したことを示唆している。すな わち, 低体温療法で脳虚血状態が改善したと考元られる。 さらに，その傾向は復温後も持続し，本治療法が重症頭 部外傷の脑酸素代謝・脳血流の改善に有用なことを示唆 している。

\section{4 感染症に対する影響}

前述のように, 血圧が低下する一方で, 血管抵抗が上 昇することは局所血流量の著明な減少を意味し，各種臓 器機能の低下を招来する。すなうち, 腎機能障害, 呼吸 器合併症, 肝機能障害など重篤な合併症の誘因となる. また，感染に対する防御機構でもある免疫機能や各種サ イトカインの反応は抑制されると考えられている4). 一 方で $34^{\circ} \mathrm{C}$ 前後の体温は細菌の発育には最も適した温度 であることから, 呼吸器感染症は必発である. 今回の検 討でも，低体温療法を 72 時間以上持続した症例は，それ 以下の症例と比較すると有意に喀痰からの細菌検出率が 高值であった $(\mathrm{p}<0.001)$. 今回の結果では約 $75 \%$ の症例 で，肺炎を合併し，しかもそれらの多くの症例の起因菌 は緑膿菌や MRSA であった。今回の死亡 11 例中 2 例は 低体温療法時に発症した呼吸器感染症によるものであっ た。本療法では, 合併症として呼吸器感染対策がきわめ て重要なポイントである。そのため，きわめて緻密な呼 吸管理や院内感染対策が必須となる。また，前述のよう に血液凝固異常や電解質異常を高率に合併することも知 られており，医師だけでなく，看護婦やその他のコメデ カルの協力が必須となる. 具体的には, 本療法導入時や 復温時にはバイタルサインがきわめて不安定となり, 当 施設では看護婦に 15〜30 分ごとのバイタルサインのチ エックを要請している，その結果, 低体温療法を行う場 合看護婦が担当可能な患者数が極端に制限されることに なる。ささに，復温時にはしばしば体温の上昇が急速と なり, 担当医の close observation が必須で, 低体温療法 を施行している患者 1 人に対して少なくとも 2 人以上の 専任主治医が必要となる。低体温下に循環・呼吸管理を
行う際には，各種心肺機能のモニターが必要であり，高 度な医療機器はもちろん，上記のようなチーム医療が必 須となる。

\section{まとめ}

脳低体温中の全身に対する影響, 特に心肺機能や呼吸 器感染症について考察した。低体温療法は脳代謝を抑制 し，それ自体が神経細胞に保護的に作用するなど利点も 多い。しかし，低体温中は心肺機能，特に血圧が低下し， 末消血管抵抗が増加することから組織血流量は極端に減 少する．また，頭蓋内圧のみでなく脳灌流圧も低下させ るため，全身血圧の維持は重要であると考えられた。し かし，脳酸素代謝が低下した低体温状況下での至適脳灌 流圧に関してはいまだ不明な点も多く，今後に残された 課題である，さらに感染症，特に呼吸器感染症はきわめ て高率に合併し，十分な対策があらかじめ必要であると 考える。

本論文の内容の一部は，第 17 回日本脳神経外科コングレス （1997 年 3 月 14 日，京都）に扔いて発表した。

\section{文 献}

1) Boelhouwer RU, Bruining HA, Ong GL: Correlations of serum potassium fluctuations with body temperature after major surgery. Crit Care Med 15:310-312, 1987.

2) Clifton GL, Allen S, Barrodale P, Plenger P, Berry S, Fletcher J, Hayers RL, Choi SC: A phase II study of moderate hypothermia in severe brain injury. $J$ Neurotrauma 10:263-271, 1993.

3) Frank SM, Beattie C, Christopherson R, Norris EJ, Perler BA, Williams GM, Gottlieb SO: Unintentional hypothermia is associated with postoperative myocardical ischemia. The Perioperative Ischemia Randamized Anesthesia Trial Study Group. Anesthesiology 78: 468-476, 1993.

4）林 成之, 雅楽川聡, 平山晃康：重症脳損傷患者のコン ピュータ管理を駆使した脳低体温療法のテクニック．脳 外速報 4：407-411，1994。

5) Martin DW, Obrist WD, Carier PM, Penrod LE, Darby JM: The use of moderate therapeutic hypothermia for patients with severe head injuries: A preliminary report. J Neurosurg 79:354-362, 1993.

6) Reed RL, Johnson TD, Hudson JD, Ficher RP: The disparity between hypothermic coagulopathy and clotting studies. J Trauma 33: 465-470, 1992.

7) Reuler B: Hypothermia: Pathophysiology, clinical setting, and management. Ann Intern Med 15:310312, 1987.

8) Safer P, Grenvik A, Abramson N: International resus citation research symposium on the reversibility of clinical death, May 1987. Crit Care Med 16:919- 
1086, 1988.

9) Shiozaki T, Sugimoto H, Taneda M, Yoshida H, Iwai A, Yoshioka T, Sugimoto T: Effect of mild hypothermia on uncontrollable intracranial hypertension after head injury. J Neurosurg 79:363-368, 1993.

10）横田裕行, 中林基明, 布施 明, 山本保博, 辺見 弘, 大塚敏文：重症頭部外傷における内頸静脈酸素飽和度測 定の意義. 医学のあゆみ 165：129-130，1993.

11）横田裕行, 小川理郎, 犬塚 祥, 小池 薫, 加藤一良, 佐藤秀貴, 布施 明, 益子邦洋, 黒川 顕, 山本保博,
大塚敏文：頭部外傷。集中治療 9:399-406，1997.

12) Yokota H, Yamamoto $Y$, Nakabayashi M, Fuse A, Mashiko K, Henmi H, Otsuka T, Kobayashi S, Nakazawa S: Continuous monitoring of jugular venous oxygen saturation in neurosurgical intensive care unit. Tokyo, Springer-Verlag, 1995, pp. 98-104.

13) Young WL, McComick PC: Perioperative management of intracranial catastrophe. Crit Care Clin 5: $821-844,1984$

重症頭部外傷における低体温療法時の循環・呼吸器合併症

\begin{tabular}{|c|c|c|c|c|c|}
\hline 裕行 & 布施 & 明 & 二宮 & 宣文 & \\
\hline 関 一英 & 黒川 & 顕 & 山本 & 保博 & \\
\hline 士郎 & 寺本 & 明 & & & \\
\hline
\end{tabular}

重症頭部外傷 39 例に対して軽度低体温療法を施行し, それらの合併症, 特に循環器系合併症や呼吸 器感染症について考察した，本治療法により，その結果頭蓋内圧は低下したが, 全身血圧も低下し, 脳灌流圧も低下した．総合的には内頸静脈酸素飽和度から頭蓋内循環動態をみると，低体温療法導入 前の脳虚血状態は導入中, 導入後改善した. ただし, 全身血管抵抗や肺血管抵抗は低体温中は増加し, 白血球や CRP などの炎症所見が悪化した。. また, 75\%の症例で肺炎が併発し, MRSA や緑膿菌な ど治療に難渋する細菌も高頻度に同定された．われわれの行つた軽度低体温療法は重症頭部外傷の治 療法として有用であつたが, 全身合併症の発現率が高かつた。 